\title{
The Journal of Therapeutic Ultrasound: broadening knowledge in a rapidly growing field
}

Robert Muratore ${ }^{1^{*}}$ and Arik Hananel ${ }^{2,3}$

\begin{abstract}
The Journal of Therapeutic Ultrasound has been established to provide an open access, online venue for the exponentially growing body of work in biomedical ultrasound therapy.
\end{abstract}

Welcome to the Journal of Therapeutic Ultrasound (JTU), a newly launched, online, open-access journal designed to accelerate the development of focused ultrasound and its adoption in the clinic.

Biomedical therapy was among the earliest applications of ultrasound, preceding solid state electronics and inexpensive computers by decades. However, there was insufficient commercialization for therapeutic ultrasound devices to be grandfathered into the Medical Device Amendments of 1976 to the United States Federal Food, Drug, and Cosmetic Act [1]. Therefore, regulatory approval is required for new therapeutic ultrasound devices in the United States. Similar regulatory burdens exist worldwide. The first such device to be approved in the United States was the Sonocare CST-100 (Sonocare, Inc., Upper Saddle River, NJ, USA), designed for the treatment of glaucoma and approved in 1988 [2]. In the year that the first patent covering the Sonocare system was filed, 1980 [3], only about 16 articles were published with the phrase 'therapeutic ultrasound' in the title. Since then, the annual number of publications in therapeutic ultrasound has been growing exponentially, reaching approximately 1,440 articles in 2011. Figure 1 demonstrates the exponential fit: the number of articles $n=2 \exp ((t-1970) / 6)$, with coefficient of determination $R^{2}=0.965$ and time constant $\tau=6$ years. In 2011, therapeutic ultrasound received attention from the popular press; following a presentation at TEDMED 2011 by Dr. Yoav Medan [4], Time Magazine named focused ultrasound therapy as one of the 50 Best Inventions of 2011 in its 2011 November 28 issue [5].

\footnotetext{
* Correspondence: wave@quantumnow.com

'Quantum Now LLC, Huntington, NY, USA

Full list of author information is available at the end of the article
}

Adoption of new International Electrotechnical Commission standards (e.g., SC62D Project Team 60601--2--62) by regulatory agencies such as the United States Food and Drug Administration (FDA), the European Commission, the Japanese Pharmaceuticals and Medical Device Agency (PMDA), and the Chinese State Food and Drug Administration (SFDA) will enable more rapid approval of devices and, therefore, more clinical applications. Thus, the exponential growth is likely to continue with a predicted output of 3,600 articles by 2015 .

In order to serve this growing demand, this journal was originally proposed by Dr. Neal Kassell, Chairman of the Focused Ultrasound Foundation, in collaboration with Dr. Lawrence Crum, Past President of the International Society for Therapeutic Ultrasound (ISTU). JTU serves as the official journal of these two organizations. The 26 members of its editorial board represent 10 countries.

The Journal accepts research articles, case reports, reviews, meeting reports, and study protocols, along with supplemental materials. Appropriate topics include translational and clinical research in all areas of therapeutic ultrasound, including stimulation, inhibition, destruction, or modification of tissue function or structure via focused ultrasound.

Peer review follows the traditional closed model with a minimum of two reviewers. Authors are encouraged to carefully follow reporting standards for ultrasound dose [6] and to follow the Journal's lead in adhering to guidelines of the Committee on Publication Ethics (COPE) [7] and the World Association of Medical Editors [8].

As an online journal, JTU offers authors unlimited color images and support for additional materials such as audio and video files. Another advantage is rapid publication following acceptance after successful completion of peer review.

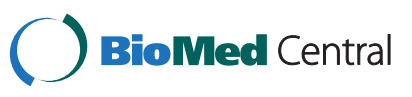

(c) 2013 Muratore and Hananel; licensee BioMed Central Ltd. This is an Open Access article distributed under the terms of the Creative Commons Attribution License (http://creativecommons.org/licenses/by/2.0), which permits unrestricted use, distribution, and reproduction in any medium, provided the original work is properly cited. 


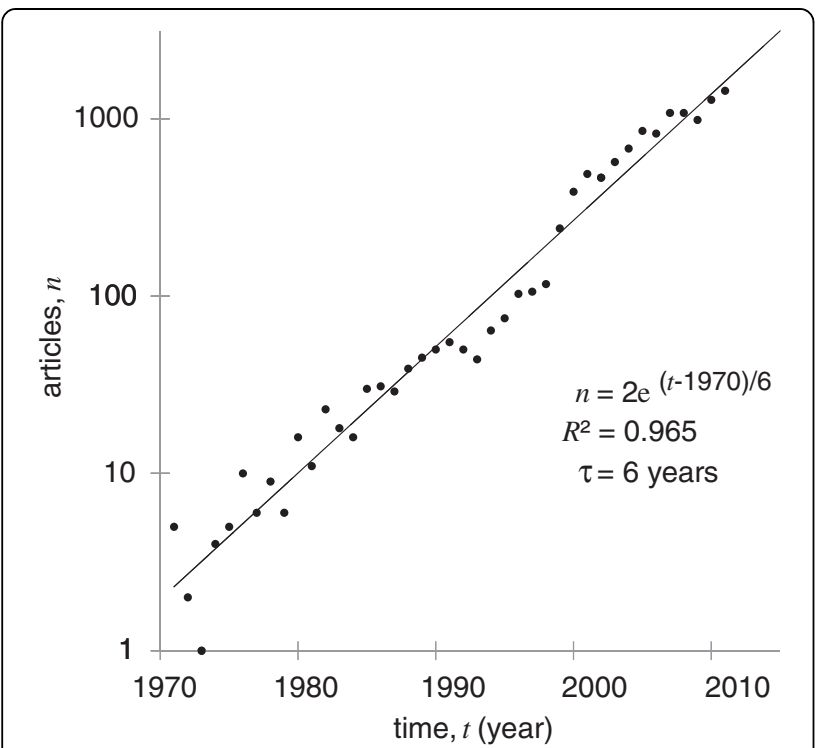

Figure 1 A Google Scholar search for the title phrase

'therapeutic ultrasound'. Restricting the search by year provides an estimate for annual publishing activity. A fitted exponential model predicts 3,600 articles in 2015.

Open access means that authors retain full rights to their articles through the Creative Commons license and that articles will reach a wide audience including developing countries and mainstream media. Articles will be deposited with PubMed Central upon publication without the 6- to 12-month delay which is common among restricted access journals.

Author fees are waived through 2014 through support provided by the Focused Ultrasound Foundation.

The Journal is intended to reach scientists and clinical practitioners interested in broadening their knowledge in the field of therapeutic ultrasound, including MRguided and ultrasound-guided focused ultrasound surgery, high intensity focused ultrasound, and non-ablative ultrasound therapies. By reaching audiences around the world, it will play a key role in advancing clinical applications of therapeutic ultrasound.

\section{Author details}

${ }^{1}$ Quantum Now LLC, Huntington, NY, USA. ${ }^{2}$ Focused Ultrasound Foundation, Charlottesville, VA, USA. ${ }^{3}$ Department of Radiation Oncology, University of

Virginia, Charlottesville, VA, USA.

Received: 12 March 2013 Accepted: 12 March 2013

Published: 25 April 2013

\section{References}

1. 21 U.S.C. 301 et seq., Medical Device Amendments of 1976 (1976 May 28), and corresponding regulations 21 C.F.R. Part 800, especially Part 814, "Premarket approval of medical devices".

2. Muratore R. A history of the Sonocare CST-100: the first FDA-approved HIFU device. In: Clement GT, McDannold NJ, Hynynen K, editors. 5th International Symposium on Therapeutic Ultrasound; 2005 Oct 27-29; Boston, Massachusetts. Melville, New York: American Institute of Physics; 2006. p. $508-12$
3. Lizzi FL, Weil KW. United States Patent 4,350,917. Frequency-controlled scanning of ultrasonic beams, issued 1982 September 21 (filed 1980 June 9).

4. Medan Y. Ultrasound surgery-healing without cuts. In: TED Talks. TED Conferences, LLC; 2011. http://www.ted.com/talks/ yoav_medan_ultrasound_surgery_healing_without_cuts.html. Accessed 2013 March 10.

5. Grossman L, Thompson M, Kluger J, Park A, Walsh B, Suddath C, et al. The 50 best inventions. In: Time Magazine. 2013. http://www.time.com/time/ magazine/article/0,9171,2099708,00.html. Accessed 2013 March 10.

6. Shaw A, ter Haar G. Telling it like it is. J Ther Ultrasound. 2013, 1:4. http:// www.jtultrasound.com/content/1/1/4

7. Wager E, Kleinert S. Responsible research publication: international standards for authors. A position statement developed at the 2nd World Conference on Research Integrity, Singapore, 2010 Jul 22-24. Chapter 50. In: Mayer T, Steneck N, editors. Promoting Research Integrity in a Global Environment. Singapore: Imperial College Press/World Scientific Publishing; 2011. p. 309-16.

8. WAME Publication Ethics Committee. Publication Ethics Policies for Medical Journals. In: World Association of Medical Editors, editor. 2013. http://www. wame.org/resources/publication-ethics-policies-for-medical-journals. Accessed 2013 Mar 10.

doi:10.1186/2050-5736-1-1

Cite this article as: Muratore and Hananel: The Journal of Therapeutic Ultrasound: broadening knowledge in a rapidly growing field. Journal of Therapeutic Ultrasound 2013 1:1.

\section{Submit your next manuscript to BioMed Central and take full advantage of:}

- Convenient online submission

- Thorough peer review

- No space constraints or color figure charges

- Immediate publication on acceptance

- Inclusion in PubMed, CAS, Scopus and Google Scholar

- Research which is freely available for redistribution 